\title{
Giant cell myocarditis associated with lymphoma: an immunocytochemical study
}

\author{
S A HALES, J M THEAKER, K C GATTER
}

From the Nuffield Department of Pathology, University of Oxford, John Radcliffe Hospital, Oxford

SUMMARY A case of giant cell myocarditis in a patient with non-Hodgkin's lymphoma is reported. To our knowledge, this is a previously unrecorded association and supports the hypothesis that the aetiology of giant cell myocarditis is related to a changed immune state. Immunohistochemical investigation of this case with a panel of monoclonal antibodies against a range of leucocyte and muscle antigens supports the view that the giant cells have a histiocytic rather than a myogenic origin.

Giant cell myocarditis is rare and is characterised histologically by florid myocarditis with large numbers of multinucleated giant cells, ${ }^{1}$ the histogenesis of which is controversial. ${ }^{23}$ The clinical course is usually rapid with progressive heart failure, arrhythmias, and death. The diagnosis is generally made at necropsy.

Although its aetiology is unknown, many previously reported cases have occurred in patients with diseases associated with an "altered immune state," particularly thymomas and organ specific autoimmune diseases. ${ }^{1245}$ We report a case of giant cell myocarditis (the first to our knowledge) in a patient

Accepted for publication 18 June 1987 with a coexistent non-Hodgkin's lymphoma-a group of tumours not uncommonly associated with changed immune state or autoimmune phenomena. ${ }^{6}$

\section{Case report}

\section{CLINICAL FEATURES}

A 59 year old man presented with shortness of breath $\overrightarrow{0}$ anorexia, and weight loss. Six months previously $h:$ had been diagnosed as having pneumonia which resolved within a month after a course of antibiotic Before admission he had had a productive cough for two weeks that had not responded to antibiotics.

Examination showed severe congestive cardiac fail-

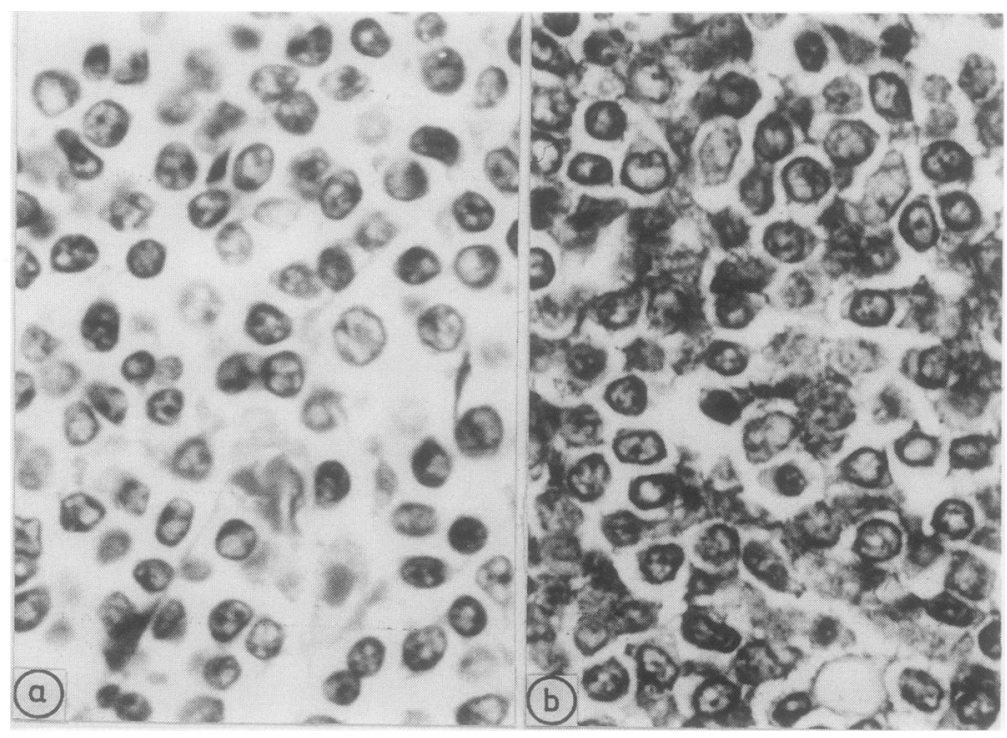

1310
Fig 1 Representative sections from lymph node to show that a) lymphoma consists of small cleaved cells typical of centrocytic lymphoma which $b$ ) are labelled as $B$ cells by ant $-B$ cell antibody 4KB5. Staining with antibodies against $T$ cells and macrophages was negative. (a) haematoxylin and eosin, b) immunoperoxidase.) 


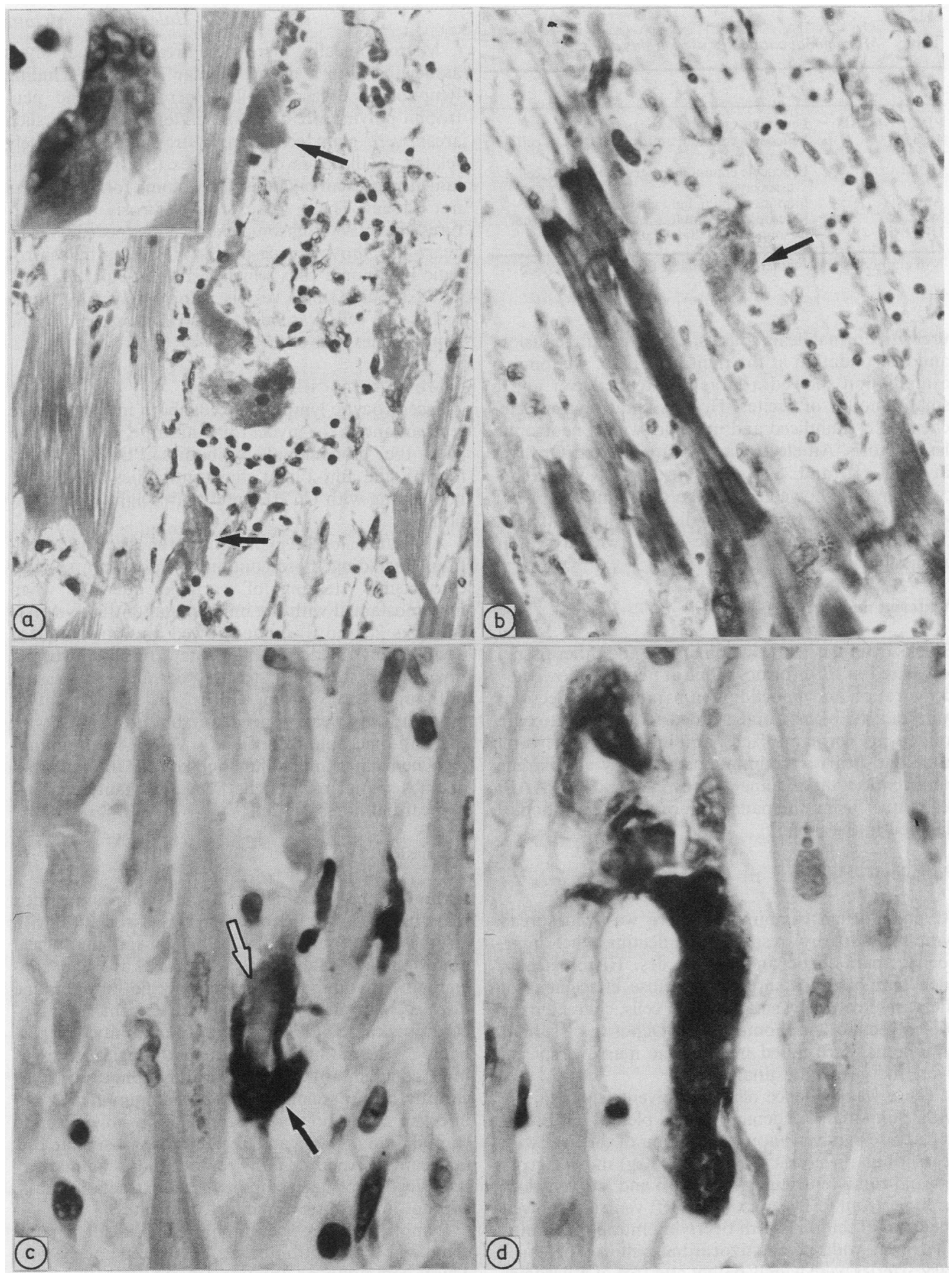

Fig 2 a) Haematoxylin and eosin stained section of heart showing typical appearances of giant cell myocarditis. Features of note are multinucleated cells (shown at higher power in insert) and myocytolysis (arrows). b) Giant cells (arrow) do not stain for desmin intermediate filaments present in adjacent muscle fibres (APAAP). c) Giant cell (solid arrow) labelled by the antimacrophage antibody MAC 387 engulfing unlabelled fragment of muscle (open arrow) (APAAP). d) Strap-like giant cell previously thought to be regenerating muscle fibres but here shown to be stained by the antimacrophage antibody $M A C 387$. Surrounding muscle fibres are unlabelled. (APAAP.) 
Table Monoclonal antibodies used in this study*

\begin{tabular}{|c|c|}
\hline Antibody & Specificity \\
\hline $\begin{array}{l}\mathrm{PD} 7 / 26+2 \mathrm{~B} 11 \\
4 \mathrm{~KB} 5\end{array}$ & $\begin{array}{l}\text { Leucocyte common antigen (CD45) } \\
\text { Leucocyte common antigen (CD45R, B cell } \\
\text { associated) }\end{array}$ \\
\hline UCHLI & $\begin{array}{l}\text { Leucocyte common antigen (CD45R, T cell } \\
\text { associated) }\end{array}$ \\
\hline $\begin{array}{l}\text { Anti } \kappa, \lambda \\
\text { MAC } 387 \\
\text { DE-R-11 }\end{array}$ & $\begin{array}{l}\text { Immunoglobulin light chains } \\
\text { Macrophage/granulocyte associated antigen } \\
\text { Desmin intermediate filaments }\end{array}$ \\
\hline
\end{tabular}

*All antibodies are commercially available from Dakopatts A/S.

ure with normal heart sounds, a right pleural effusion, and consolidation at the right lung base. Abdominal examination showed a large non-tender liver and a small amount of ascites. He was clinically and biochemically jaundiced and uraemic, with a neutrophil leucocytosis. An electrocardiogram showed $Q$ waves in lead III and ST elevation in $V_{2}-V_{4}$. Echocardiography showed a dilated poorly functioning left ventricle. He was treated with diuretics and inotropes, but died following a cardiac arrest two days after admission.

\section{Material and methods}

Blocks from the heart, lymph nodes, and other tissues were fixed in $10 \%$ formol saline at $\mathrm{pH} 7 \cdot 4$ followed by dehydration and embedding in paraffin wax. Sections were cut at 3-5 $\mu \mathrm{m}$ and stained with haematoxylin and eosin. Formalin fixed paraffin sections of lymph node and heart were immunostained by an alkaline phosphatase-antialkaline phosphatase (APAAP) technique ${ }^{7}$ using the panel of monoclonal antibodies detailed in the table.

\section{Pathology}

At postmortem examination there was widespread lymphadenopathy, especially affecting the hilar, coeliac, para-aortic and iliac nodes. Histologically, such lymph nodes showed a diffuse effacement of their architecture by small cleaved cells, characteristic of centrocytic lymphoma (fig 1). Deposits of similar lymphoma were noted in the bone marrow, spleen, liver, and gastrointestinal tract.

There was evidence of severe biventricular failure with pulmonary oedema, serous pleural effusions, and severe passive venous congestion of the liver with centrilobular necrosis. The heart $(450 \mathrm{~g})$ showed gross left and right ventricular dilatation and left ventricular hypertrophy. The apex of the left ventricle showed aneurysmal thinning with overlying mural thrombus. There was widespread myocardial pallor. The coronary arteries were widely patent and free of atheroma.
Microscopically, there were areas of myocytolysis associated with a mixed cellular infiltrate including lymphocytes, plasma cells, macrophages and neutrophil polymorphs (fig 2a). Scattered widely in such areas were giant cells, many strap-like and closely related to the ends of myofibres (fig 2). Some contained lipofuscin pigment. Granuloma formation was not evident. There was extensive fibrosis. These features are those of chronic giant cell myocarditis. The heart also showed widespread infiltration by centrocytic lymphoma cells which were particularly aggregated around small vessels. Morphologically, these lymphoma cells were identical with those seen in the lymph nodes and other sites.

\section{IMMUNOHISTOCHEMISTRY}

The centrocytic lymphoma cells, both in lymph node sections and in the myocardial infiltrate, were positive with the monoclonal antibodies PD7/26, 4KB5 (fig $1 \mathrm{~b}$ ), and anti- $\lambda$ light chain antibodies but showed no staining with UCHL1 and anti- $\kappa$ light chain antibodies.

About $80 \%$ of the giant cells in the myocardial sections, including those containing lipofuscin, showed cytoplasmic staining of variable intensity when immunostained with the monoclonal antibody MAC 387 (figs $2 \mathrm{c}$ and d); none showed any positivity for desmin intermediate filaments (fig 2b). Normal myofibres showed strong desmin expression (although "necrotic myofibrils" in areas of myo-e. cytolysis were weak or negative), but no staining with? the anti-macrophage antibody MAC 387 . Immunocytochemical staining highlighted the intimate but distinct spatial relation between the giant cells and myocardial fibres (fig 2c).

\section{Discussion}

Although the aetiology of giant cell myocarditis remains unknown, there is a striking association with diseases commonly characterised by immunological abnormalities. Many reported cases have had concomitant thymomas or organ specific autoimmune diseases. $^{1245}$ This could mean that giant cell myocarditis is caused directly by "autoimmunity", or perhaps, by the modulation of the pathological changes in a concomitant case of viral lymphocytic myocarditis in a patient with "altered immunity". No infective agent, however, has yet been shown despite careful study, ${ }^{18910}$ and furthermore, a similar disease can be experimentally reproduced in animals by the injection of heterologous heart extracts - that is, without implicating any infective agents. ${ }^{11}$

Lymphomas are commonly associated with a change in the function of the host's immune system. This is commonly an immune deficiency which predis- 
poses patients to a wide range of infections or abnormal immune responses with autoimmunity (such as haemolytic anaema ${ }^{6}$ ). In the present case the lymphoma might be related to the giant cell myocarditis by a predisposition to infection, autoimmune phenomena, or a combination of both.

The histogenesis of the giant cells in giant cell myocarditis remains controversial. By light microscopy, giant cells are often seen in immediate proximity to myocardial fibres and can contain large amounts of lipofuscin. Such observations led to the view that the giant cells were of muscle origin, and this has been supported by electron microscopy ${ }^{3}$ and an immunohistological study in which the presence of myoglobin was shown in the giant cells. ${ }^{12}$ Studies attempting to show the histiocyte marker lysozyme in the giant cells have supported ${ }^{9}$ and refuted ${ }^{10}$ a histiocytic origin. A recent report, however, ${ }^{8}$ in which frozen tissue was available for study by immunocytochemistry using a range of monoclonal antimacrophage and muscle antibodies, suggested that the giant cells were of histiocytic origin.

In the present case most of the giant cells stained positively using a macrophage marker (not known to cross react with muscle), including the strap-like giant cells adjacent to myofibres and those containing large amounts of lipofuscin. None expressed desmin, the characteristic intermediate filament of muscle. These results support the view that the giant cells in giant cell myocarditis (or at least most of them) are histiocytic in origin. How can this be reconciled with reports of the presence of myoglobin in the giant cells? It has been suggested that this is secondary to phagocytosis by macrophages following damage to muscle cells, ${ }^{8}$ and, indeed, myoglobin has been noted in macrophages within myocardial infarcts and tumour cells infiltrating skeletal muscle. ${ }^{13}$ If this is true for myoglobin then why did we find no staining for desmin in the giant cells? A possible explanation comes from the observation that some of the necrotic muscle cells (those most closely associated with the giant cells) did not express desmin. This suggests that the antigenic determinant is lost during cellular degeneration and is therefore not available for phagocytosis.
KCG is a Wellcome Trust senior research fellow in clinical science. We thank Dr M Benson for permission to report on this case, A Heryet for technical assistance, and Miss Lesley Watts for typing the manuscript.

\section{References}

1 Davies MJ, Pomerance A, Teare RD. Idiopathic giant cell myocarditis. A distinctive clinico-pathological entity. Br Heart $J$ 1975;37:192-5.

2 Langston JD, Wagman GF, Dickenman RC. Granulomatous myocarditis and myositis associated with thymoma. Archives of Pathology 1959;68:367-73.

3 Pyun KS, Kim YH, Kalzenstein RE, Kikkawa Y. Giant cell myocarditis-light and electron microscopic study. Archives of Pathology 1970;90:181-8.

4 Burke JS, Medline NM, Katz A. Giant cell myocarditis and myositis. Associated with thymoma and myasthenia gravis. Archives of Pathology 1969;88:359-66.

5 Hudson R. Giant cell myocarditis. In: Cardiovascular pathology. Vol 3. London: Edward Arnold, 1970;498-800.

6 Hamblin TJ, Oscier DG, Young BJ. Autoimmunity in chronic lymphocytic leukaemia. J Clin Pathol 1986;39:713-16.

7 Cordell JL, Falini B, Erber WN, et al. Immunoenzymatic labeling of monoclonal antibodies using immune complexes of alkaline phosphatase and monoclonal anti-alkaline phosphatase (APAAP complexes). $J$ Histochem Cytochem 1984;32:219-29.

8 Theaker JM, Gatter KC, Heryet A, Evans DJ, McGee JO'D. Giant cell myocarditis: evidence for the macrophage origin of the giant cells. J Clin Pathol 1985;38:160-4.

9 Rabson AB, Schoen FJ, Warhol MJ, Mudge GH, Collins JJ Jr. Myocarditis after mitral valve replacement: case report and studies of the nature of giant cells. Hum Pathol 1984;15:585-7.

10 Tubbs RR, Sheibani K, Hawk WA. Giant cell myocarditis. Arch Pathol Lab Med 1980;104:245-6.

11 Laufer A, Davies AM. Experimental granulomatous myocarditis: Genesis and immunological aspects. Ann NY Acad Sci 1969;156:91-104.

12 Tanaka M, Ichinohasama R, Kawahara Y, et al. Acute idiopathic interstitial myocarditis: case report with special reference to morphological characteristics of giant cells. J Clin Pathol 1986;39:1209-16.

13 Eusebi V, Bondi A, Rosai J. Immunohistochemical localization of myoglobin in nonmuscular cells. Am $J$ Surg Pathol 1984;8:51-5.

Requests for reprints to: Dr JM Theaker, Nuffield Department of Pathology, University of Oxford, John Radcliffe Hospital, Oxford OX3 9DU, England. 